\title{
Use of Crowdfunding for Developing Social Enterprises: An Islamic Approach
}

\author{
Nazamul Hoque ${ }^{1}$, Mohammad Hasmat Ali ${ }^{2}$, Sirajul Arefeen ${ }^{3}$, Md. Masrurul Mowla ${ }^{1} \&$ Abdullahil Mamun ${ }^{1}$ \\ ${ }^{1}$ Department of Business Administration, International Islamic University Chittagong, Bangladesh \\ ${ }^{2}$ Department of Finance, University of Chittagong, Bangladesh \\ ${ }^{3}$ Vice-Chancellor's office, International Islamic University Chittagong, Bangladesh \\ Correspondence: Nazamul Hoque, Department of Business Administration, International Islamic University \\ Chittagong, Bangladesh. E-mail: nazam_iiuc@yahoo.com
}

Received: March 20, 2018

doi:10.5539/ijbm.v13n6p156
Accepted: May 4, 2018

URL: https://doi.org/10.5539/ijbm.v13n6p156

\begin{abstract}
Crowd-funding is an open call to mass people through the internet for fund in the form of financial donation, lending, or in any other forms such as in exchange for a future product, service, or reward. The concept is relatively new but growing at a very high rate around the world. Companies are using it mostly for efficiency ground. This study is based on the argument that conventional crowd-funding models cannot be applicable exactly in the Islamic societies due to philosophical ground. In this paper, we have discussed crowd-funding models from Islamic perspectives for funding projects of social enterprise/social business in the Muslim societies with a view to ensure social equity and justice by removing many social problems like unemployment and poverty.
\end{abstract}

Keywords: social enterprise, crowdfunding, Islam, Muslim society

\section{Introduction}

Crowdfunding is a mechanism by which businesses enterprises or any other organizations collect necessary fund in the form of either investments or donations from numerous individuals to fulfill the financial requirements (World Bank 2013). It is an open call through the internet for monetary resources in the form of a financial contribution, on occasion in exchange for a future reward, service, or product (Gerber et al 2012, Belleflamme et al 2014; Kleemann et al 2008). The concept of crowdfunding derives from the notion of crowdsourcing which is the use of expertise and creativity of a great number of people, subcontracted to do some jobs usually performed by employees in the organizations (Howe, 2006). This innovative type of capital formation came into sight in an organized way in the wake of the financial crisis of 2008 when entrepreneurs, artisans, and early-stage enterprises mostly faced difficulties in raising funds. Entrepreneurs started to look elsewhere for capital when traditional banks were less willing to provide loans (World Bank, 2013). Crowdfunding uses internet to facilitate transactions between funders (people who give money) and creators (people who request funds). Crowdfunding platforms, such as Indie GoGo, Kickstarter, and RocketHub provide facilities for anyone with Internet access to collect funding to realize their work. Initiators/creators create a profile on a crowdfunding platform and make clear their planned use of the funds, financial goals, and timeframe for achieving their goals. As an instance, two friends with an innovative idea but no link to fund raised USD $\$ 306,944$ in thirty seven days to build up a coffee warming product on a crowdfunding platform (Gerber et al 2012). In the process of identifying crowdfunding, they developed a novel coffee product, promoted the idea, managed finances and customers, and supplied a product. Funders who promised $\$ 40$ or more obtained the innovative product while the fundraising objective was realized.

Around the world, the use of 'crowdfunding' is gradually increasing (Schwienbacher \& Larralde 2010) because of its multidimensional benefits both for business organizations as well as fund providers. According to Crowdsoursing.org (2013) the crowdfunding market is of $\$ 5.1$ billion in 2013 having $81 \%$ growth compared to 2012. It is expected that over time, crowdfunding can play significant roles in ensuring the economic growth of many countries because it allows large number of individuals to engage as consumers and producers (Schwienbacher \& Larralde 2010). According to World Bank (2013), 45 countries of the world have active 
crowdfunding platforms (See Table 1).

Table 1. The Number of Crowdfund Investing platforms (CFI) in selected countries

\begin{tabular}{llll}
\hline Country & $\begin{array}{l}\text { Number of CFI } \\
\text { Platforms }\end{array}$ & Country & $\begin{array}{l}\text { Number of CFI } \\
\text { Platforms }\end{array}$ \\
\cline { 2 - 3 } United States of America & 344 & Brazil & 17 \\
United Kingdom & 87 & Australia & 12 \\
France & 53 & South Africa & 4 \\
Italy & 15 & India & 10 \\
Spain & 27 & China & 1 \\
Germany & 26 & Russian Federation & 4 \\
Netherlands & 34 & United Arab Emirates & 1 \\
Canada & 34 & Estonia & 1 \\
\hline
\end{tabular}

Source: World Bank (2013).

Though the concept of 'crowdfunding' was originated in the developed countries and still largely a developed-world phenomenon but this concept has very high potentiality in the developing countries as well; because, funding the projects is more an issue in the developing countries as compared to developed countries due to lack of sufficient number of financial institutions in the developing countries. So, developing countries have very high prospect to manage growth by using crowdfunding mechanism (World Bank 2013).

Similarly, 'crowdfunding' has very high potentiality in the Muslims societies for developing business enterprises because in one side, most of the Muslim countries lack sufficient numbers of financial institutions and in another side, Muslim societies have many people having small amount of money to donate /and invest. But, this study has focused mainly on the development of social business enterprise or social enterprise; because, Islam highly emphasizes on the social welfare issue and social wellbeing is the most crying demand in the Muslim societies due to having high rate of social inequity, unemployment and poverty in Muslim societies. Considering the social welfare aspect of society, Islam has prohibited interest, Riba (Quran: 2: 275), made the Zakah compulsory (Quran 9:60) for the solvent Muslims and charity is given very high importance (Quran: 2:261). But, still Muslim societies are not free from many social problems like social inequity, unemployment and poverty and how Muslim societies can be freed from such problems still this debate is going on among the academia, policy makers, social thinkers and civil society. In this regard, it is the proposition of this study that by developing sufficient numbers of social enterprises, the problems like unemployment, inequality and poverty can be solved and social wellbeing can be ensured; because, social enterprises are formed for maximizing the benefits of society not profit (Biztaxlaw, 2013). But social entrepreneurs in the Muslim societies often face a problem of fund for developing and managing social enterprises.

The paper proceeds as follows. In Section 2 we present literature on crowd-funding and social enterprise. In Section 3 we discuss the prospects of crowd-funding for developing social enterprises in Muslim courtiers. Section 4 discusses the models of crowd-funding from Islamic perspective. Finally, section 5 presents conclusion and policy implications.

\section{Review of Literature}

\subsection{Concept of Crowdfunding}

Though today's style of crowdfunding is new but the basic notion of crowdfunding is old. The presence of crowdfunding was there in different forms and styles such as in the late middle age there ware systems of (family) partnership (Lane, 1944), benevolent fund-raising (Bremner, 1996; Ingenhoff \& Koelling, 2009) and micro-finance (Morduch, 1999). Yet, due to the advancement of communication and information technology, the system of collecting fund from many people in different models is modified and changed. According to Belleflamme et al. (2014), many creative business initiatives remain unfunded as they either don't have necessary resources to satisfy the funding institutions such as banks and equity capitalists or they cannot convince many specialized investors such as venture capitalists and business angels. This circumstances has motivated the entrepreneurs to search for a new avenue of finance "Crowdfunding". Crowdfunding is derived from the broader idea and notion of crowdsourcing. Jeff Howe and Mark Robinson first used the term "crowdsourcing" in Wired Magazine in the June 2006 issue (Schwienbacher \& Larralde, 2010, Rubinton, 2011). 
In literature, the term 'crowd' has been defined as a large group of people contributing each little, but having high joint impact (Belleflamme et al., 2014, Lehner, 2013). Howe (2008) defined Crowdsourcing as a way to harness the innovative solutions with the combined efforts of individuals. According to Rubinton (2011), crowdsourcing is a deliberated and planned initiative for materializing a goal by the combined efforts and supports of large number of people in exchange of value in any form. Lambert and Schwienbacher (2010) opined that the vision of crowdfunding is to use the power of the crowd/people to finance projects or ventures by using crowdfunding platforms or social networks, such as Facebook, Myspace, and Twitter. For materializing the vision, crowdfunding platforms can provide necessary supports to creators and funders for exchanging resources. Before using computer-mediated crowdfunding, creators often engaged in personal crowdfunding initiatives. For example, musicians may ask publicly to their fans to finance a new tour or album. Rapid-growing crowdfunding platforms may now finance a various range of projects and ventures, such as film, fashion, software, and product design (Gerber et al 2012) and it can be used for developing various types of enterprises regardless of its nature and types such as social enterprise, social business enterprise and business enterprises.

\subsection{Why Do Companies Use Crowdfunding?}

Companies can use crowdfunding mainly for reducing the cost (Kleemann et al., 2008). By involving in the product improvement and design, users contribute to creating value for the organizations. Companies can easily raise fund by crowdfunding because crowdfunders provide small amounts individually; consequently, their risk is minimum. Furthermore, the crowd may be customers when the product is brought to the market and they can also disseminate the information about the product if they have a share in the profits of the venture (Schwienbacher \& Larralde, 2010). Company can also to reduce the duration of new product development, its costs, and can increase customer acceptance. People and/or Consumers supply necessary fund to the organization to make its investments for various purposes such as for acquiring new assets or paying the employees (Schwienbacher \& Larralde, 2010). Crowds can be more effective and efficient at times than small teams or individuals (Howe, 2008). According to Brabham (2008), the composition of crowd can act as efficiency because the more varied it is, the more efficient it can be. In fact, the 'wisdom of crowd' is because of crowd's solutions aggregating to each other, as compared to averaging out(Surowiecki, 2004). It is very interesting to note that the members of the crowd may solve their problems by allowing the people of diverged background. Lévy (1997) opined interestingly about "collective intelligence". To him 'everyone knows something', 'no one knows everything, and all knowledge resides in humanity'. Thus, it is clearly demonstrate that crowdfunding can be a center of knowledge and wisdom (Schwienbacher \& Larralde, 2010).

\subsection{Why Do Crowdfunders Invest Money?}

The motivation for investing in Crowdfunding (CF) can be financial return, social return, and material return (De Buysere et al., 2012). The expectation of returns depends on the intrinsic or extrinsic motivating factors the crowd (Collins \& Pierrakis, 2012; Lehner, 2013; Ordanini et al., 2011; Belleflamme et al., 2014). According to De Buysere et al. (2012) geographical or emotional attachment of crowd to the project or ventures can also be an important factor of motivation.

\subsection{Models of Crowdfunding}

According to Ordanini et al. (2011) generally crowdfunding (CF) models have examples of social cooperation and charity, but consumers may invest money to have a return, mainly and mostly financial along with intangible such as social esteem, status, and recognition. Therefore, categorisation is primarily on the basis of motivation of crowd making the contribution and the returns on investment (ROI) (social return; financial return and material return) expected from this investment. Table 2 presents the four types of conventional CF models along with a detailed picture of the characteristics of each of the four types of CF models. 
Table 2. The different types of models of crowdfunding

\begin{tabular}{|c|c|c|c|}
\hline Type & $\begin{array}{l}\text { Form of } \\
\text { Contribution }\end{array}$ & Form of Return & Motivation of crowd/funder \\
\hline Donation & donation & intangible benefits & intrinsic and social \\
\hline Crowdfunding & & & \\
\hline Reward & donation/ & rewards but also intangible benefits. & Combination of intrinsic and social \\
\hline Crowdfunding & Pre-purchase & & motivation and desire for reward \\
\hline Lending CF & Loan & $\begin{array}{l}\text { Repayment of loan with interest. Some socially } \\
\text { motivated lending is interest free. }\end{array}$ & $\begin{array}{l}\text { Combination of Intrinsic, social and } \\
\text { financial motivation(Getting back the } \\
\text { lending capital) }\end{array}$ \\
\hline Equity CF & Investment & $\begin{array}{l}\text { ROI if the business is success. Rewards may also } \\
\text { be offered. Intangible benefits another factor for } \\
\text { many investors. }\end{array}$ & $\begin{array}{l}\text { Combination of Intrinsic, social and } \\
\text { financial motivation. }\end{array}$ \\
\hline
\end{tabular}

Source: Collins \& Pierrakis (2012).

\subsection{Concept of Social Enterprises}

Social enterprises are 'social objective driven' organizations. These include both for-profit and not for-profit (Biztaxlaw, 2013, Molla 2012) and may be a mutual organization and co-operative (Biztaxlaw, 2013), a charity organization or a social business (Ridley-Duff et al., 2011). These are similar to business operations but not for doing business like the classical business organization (Molla 2012). The explicit aims of social enterprises are mainly to benefit the society and community (Nyssens, 2006). Social enterprise have to fulfill a social need but at a profit necessary to be economically sustainable (Molla, 2012). Generally, market-based business approach is applied by social enterprises in their operations to achieve social objectives. These can be organized in different names in different societies and countries. It is not out-and-out a charity and benevolent function. In fact, it is, based on the philosophy that can be explained as 'doing charity by doing trade', rather than 'doing charity while doing trade' (Molla, 2012). Though most social enterprises are fragile, and many are small, the sector has been receiving growing interest and curiosity from entrepreneurs, policymakers, funders, young people, and established businesses (Leadbeater, 2007) due to its social and welfare aspects. The founder of Microsoft, Bill Gates, explained in June 2007 in his inauguration speech at Harvard, why he had decided to donate $\$ 39 \mathrm{bn}$ in different projects relating to inequalities in education and health mainly affecting children. According to Bill Gates, around the world many children of developing countries died due to systemic errors. He opined that market forces should be designed and developed for providing the benefits to the poor. The governments of the world should spend the money of taxpayers in a planned and deliberately for generating the meaningful and effective fruits for the poor.

\subsection{Types of Social Enterprises}

Social enterprise has a contested and mixed heritage because of its cooperative roots in the United Kingdom and charitable roots in the United States, and, Asia and European Union (Ridley-Duff et al., 2011). In the United States of America, the name is related with 'doing charity by doing trade', rather than 'doing charity while doing trade'. There are also countries, where priority is given on democratic control of capital rather than charity (Kerlin, 2009). Recently, there is an increasing trend in doing social business along with traditional business operations due to having consciousness among the people (Ridley-Duff \& Southcombe, 2011). Social enterprise may be classified into four, such as:

\section{i. No cost recovery \\ ii. Some cost recovery \\ iii. Full cost recovery \\ iv. More than full cost recovery \\ 2.7 Motivation for Social Enterprise}

In the human civilization and history there was a Social enterprise with different forms and styles. Thus, the history of social enterprise is as old as human civilization. In the world, there are many people who get satisfaction by cooperating and supporting other people (Yunus, 2007). Every single religion has encouragement and inspiration for helping others. Furthermore, earning reasonable profit can also be the source of motivation for social entrepreneur along with other intrinsic factors of motivation. Indeed, reasonable profit or small amount of profit is the valid right of social entrepreneur and without profit entrepreneur will not be motivated to continue his business and even they cannot survive in business (Molla, 2012). For this reason, the reasonable profit or 
normal profit is to be calculated as a part of economic cost. Indeed, the 'not for-profit' business concerns have some fundamental problems for which they couldn't grow and develop on the own foot and thus seeking donation or charity has become the common phenomenon for them.

\subsection{What People Can Donate/Invest in Social Enterprise?}

People can donate their time, knowledge, skills, money, and things (Leadbeater 2007) on the basis of their ability, interest and likings. Those who have sufficient fund they can contribute/donate money for developing social enterprise and around the world there are many rich philanthropists who can create venture philanthropy funds. Even the people who have small amount fund they can contribute their valuable time. Fifty five percent $(55 \%)$ people of United States of America, spend some time every year for the wellbeing and welfare of society which is equivalent to more than nine million full-time employees, worth $\$ 239$ billion, almost as much as the amount donated in money, \$269 billion.

Moreover, donations of fund and other material resources are still very important to many social organizations and enterprises and disadvantageous and underprivileged community. In this regard blood donation can be considered as a model. Another example is the USA social enterprise GoLoco, which is using social networks to allow people to share. People of the world can also contribute and give their knowledge, skills, and expertise for helping the community people. Wikipedia is a living example of this model. Indeed, it is the pioneer in this regard. Now this model is being taken up in the UK by the School of Everything created by the social entrepreneur Paul Miller, which aims to be a learning exchange. Furthermore, one of the most promising global social enterprises is One World Health which uses unwanted intellectual property donated by large pharmaceutical companies to address diseases in the developing world.

\subsection{Need for Social Enterprises in Muslim Societies}

Unfortunately, $44 \%$ of world's 1.7 billion poor (The Nation 2011) or $35 \%$ (World Bank 2010) are living in the different Muslim countries of the world (Hoque et al., 2015). So, Social enterprises are badly needed in the Muslim societies for ensuring social equity and social wellbeing. Since social enterprises do not seek unreasonable or excessive profit, they generate much social wellbeing. If developed properly the social enterprises bring changes for mainstream business enterprises in terms of doing business in more socially responsible and inclusive ways. They can also encourage customers to demand such goods and service (Leadbeater 2007).

\subsection{Prospects of Social Enterprises in Muslim Societies}

Charity or donation is the fundamental and basic duties of every single Muslim. Giving a certain amount to the needy and poor from the yearly savings of a solvent Muslim is the religious duties. It is one of the five pillars of Islam. For distributing the charities and donations of muslims among the poor people, the social institution of "Awqaf" arose in early Islamic societies. "Awqaf" is the plural form of "waqf," meaning "standing trust," or "charitable endowment". The Almighty Allah says, "Those who spend their resources in the path of Allah it is like a grain (of corn) that grows seven ears, and each ear has a hundred grains (Quran 2:261). It means the reward of charity is 700 times higher and Allah the almighty can give more than that.

Prophet Muhammad(SAW) says, "When a person dies, all of his/her acts come to an end, except three: "sadaqah jariyyah," (recurring or ongoing charity, or waqf); beneficial knowledge shared with others; and a pious child (son or daughter), who prays for the deceased person."

Human welfare is fundamental concern of Islam. Islam has given very high importance on the wellbeing of people (Quran 2:201). Ever, a Muslim jurist unanimously opined that is the fundamental goal of Shariah is nothing but ensuring the welfare of the people and reducing their hardships (Chapra, 1985). Islam desires welfare of this composite life (Quran 28:77). The vision of Islam is to ensure social wellbeing (Quran, 57:27). Allah says that all the resources have been created for the welfare of mankind (Quran, 2:22). Man should take the necessary initiatives to explore them and use them in a efficient and effective way so that people can enjoy the real fruits of it and thereby their needs can be fulfilled (Qur'an 28:77). Allah (SWT) asks people to search for his bounties where the prayer is over (Quran, 62:10).

In fact, Islam as a religion of nature (deen alfitar) has a desire to build or portrait a society having absolute economic and social justice for all human being regardless of color, caste, and gender (Choudhury, 2002). But, Islamic teaching of social justice, and brotherhood would be meaningless unless and until economic justice is ensured (Hoque et al., 2015). To materialize this social justice, therefore, all the resources of the world should be utilized efficiently and proper distributive mechanism as envisaged in Islam should be applied (Sadeq 1996, Hoque et al., 2015). Hence, Islam emphasizes wealth mobilization through the creation of business enterprises. 
Indeed, resources are mobilized and people are highly benefited when people develop sufficient number of social enterprises. Considering the importance of multidimensional benefits of social enterprises Islam highly emphasizes on the creation of social enterprises. Fortunately, presently the total number of Muslim population is 1.62 billion and rising with high rate and expected to be 2.2 billion by 2030 (Pew Research Centre 2014). Furthermore, Muslims are possessing $70 \%$ energy resources and $40 \%$ natural resources of the world (Laghari 2013). Social enterprises can create a good demand of their products by appealing to general people for buying the products of social enterprises. Of course, if social enterprises can produce quality products and sell with reasonable price then customers will certainly buy the products of social enterprises. So, social enterprises have very high prospect in Muslim society.

\section{Prospects of Crowdfunding in Muslim Society for Developing Social Enterprises}

Entrepreneurs are the engines that drive new companies and financing is the fuel that propels them (Bygrave 2003). There is a bright prospect of crowdfunding in Muslims' society for developing Islamic social enterprises mainly because of having large numbers fund providers/investors who will ultimately be the customers and consumers of the products of social business enterprises. Furthermore, people (crowd) can donate/and invest small amount of fund, donation/charity is the community character of Muslims and presently Muslims are 1.62 billion of which many have ability and mentality to donate or /and invest for social enterprise.

Unfortunately, in spite of having clear and sharp directions in Islam regarding the establishment and management of social enterprise/business enterprises, most of the Muslims still pay little attention to the social enterprise development. This is because, in one side, many Muslims lack sufficient knowledge about different funding mechanism such as crowdfunding and on the other side, there is an absence of clear guide lines in crowdfunding from Islamic point of view. Though, Collins \& Pierrakis (2012) proposed models (discussed in the literature section) of crowd-funding, but, these models cannot be exactly applied in the Islamic societies because of shariah issue.

In this article, therefore, the authors took interest to highlight the models of crowdfunding from Islamic perspective. The rationale of the study lies in the fact that through literature review the authors found no comprehensive research regarding crowdfunding from Islamic perspective. There are few studies in this line but they are not fully and analytically written from the Islamic point of view. This study is a desk-based and library-oriented research. To discuss the Islamic framework of crowd-funding, the authors reviewed the Holy Quran, Sunnah (the sayings of Prophet Muhammad SAW), available published literatures, research monograms, journal and magazines in this field.

\section{Models of Crowd-Funding from Islamic Perspective}

Table 3 presents the four types of Islamic CF models (modifying the conventional CF models) along with a detailed picture of the characteristics of each of the four types of CF models.

Table 3. The different types of models of crowdfunding from Islamic perspective

\begin{tabular}{|c|c|c|c|}
\hline Type & Form of Contribution & Form of Return & Motivation of crowd/funder \\
\hline Donation CF & $\begin{array}{l}\text { Sadaqa (no monetary returns } \\
\text { expected) }\end{array}$ & $\begin{array}{l}\text { Intangible benefits. } \\
\text { (satisfaction of helping the } \\
\text { needy people of society) }\end{array}$ & $\begin{array}{l}\text { Intrinsic and social Motivation } \\
\text { (satisfaction of Allah, Salvation in the } \\
\text { hereafter, getting Jannat, Escaping from } \\
\text { hellfire etc) }\end{array}$ \\
\hline Reward CF & Sadaqa/Pre-purchase/Pre-sales & $\begin{array}{l}\text { Recognition, rewards and } \\
\text { intangible benefits }\end{array}$ & $\begin{array}{l}\text { Intrinsic and social Motivation with a } \\
\text { desire for reward here and hereafter. }\end{array}$ \\
\hline $\begin{array}{l}\text { Qardee Hasana/ } \\
\text { Interest free loan }\end{array}$ & $\begin{array}{l}\text { Qarde Hasana/ Interest free } \\
\text { loan) }\end{array}$ & $\begin{array}{l}\text { Intangible benefits. } \\
\text { (satisfaction of helping the } \\
\text { needy people of society) }\end{array}$ & $\begin{array}{l}\text { Intrinsic and social Motivation a) } \\
\text { satisfaction of Allah, Salvation in the } \\
\text { hereafter, getting Jannat, Escaping from } \\
\text { hellfire etc. } \\
\text { b) Getting back the lending capital }\end{array}$ \\
\hline Equity CF & Investment & $\begin{array}{l}\text { ROI if the business is success. } \\
\text { Rewards may also be offered. } \\
\text { Intangible benefits another } \\
\text { factor for many investors. }\end{array}$ & $\begin{array}{l}\text { Combination of Intrinsic, social and } \\
\text { financial motivation(Very small amount } \\
\text { of profit say } 3-5 \% \text { ) }\end{array}$ \\
\hline
\end{tabular}

Source: CF types \& properties (extended and modified from Collins \& Pierrakis, 2012). 
Fortunately, many social enterprises are working in Muslim societies for alleviation of poverty as well as for providing service to the poor but most of the social enterprises are charity/ donation based (See Figure 1) and lack income generating projects; consequently seeking donation (charity) continuously has become the common phenomenon of social enterprises and the development of social enterprises are not occurring as per their potentiality. In this regard, crowdfunding can be a good tool to generate sufficient fund for developing social enterprises in the Muslim societies because it is difficult to collect big amount of fund from a few people but it is easier to collect big amount of fund from large number of people (crowd). Moreover, the base of social enterprises (see figure 2) would be strong if different models of crowdfunding are used properly. So, this is the argument of this paper that by using different models (Donation, Reward, Qardee Hasana, and equity) of crowdfunding, the development of social enterprises can be accelerated in the Muslim societies; consequently many social problems like inequity, unemployment and poverty can be solved.
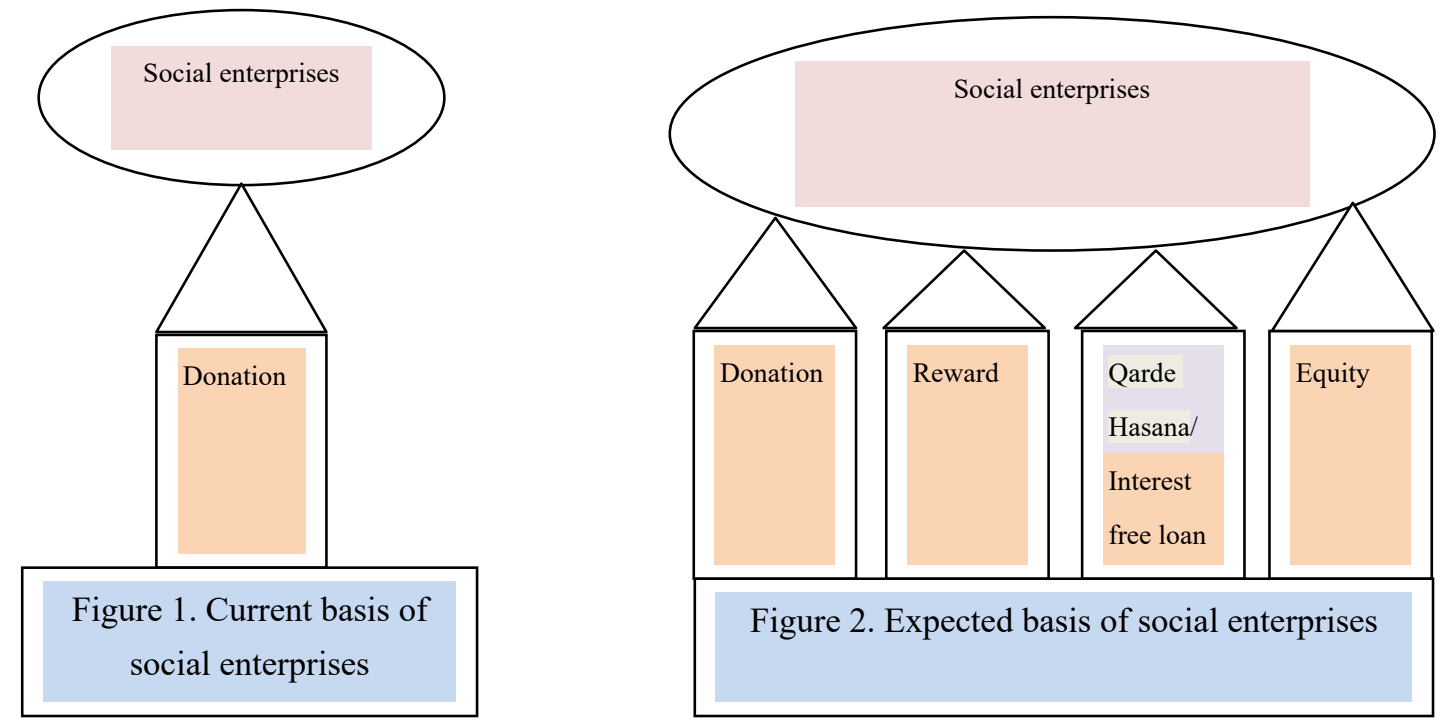

\section{Conclusion and Policy Implications}

With the passage of time, the social enterprise field has become increasingly well-populated in the world. In some areas social enterprises are growing and continue to grow in scale and number (Leadbeater, 2007). Unfortunately, most of the social enterprises have no income generating projects and following only donation/charity model consequently the developments of social enterprises are not occurring as per the potentiality. But, the social entrepreneurs can use different models of crowdfunding (Like donation, lending, Qardee Hasana, and equity) for developing social enterprises in different areas as well as different types (no cost recovery, some cost recovery, full cost recovery and more than full cost recovery) and can challenge the profit maximizing business enterprise (PMEs) and social enterprise can act as a catalyst for further change in other sectors of the economy. Of course, social enterprises are facing some challenges in Muslim world such as lack of favorable government policy, lack of crowdfunding platforms and lack of skilled social entrepreneurs. But the prospect of developing social enterprises by crowdfunding is very bright because of having religious inspiration as well as having huge number of potential donor, lenders and investors in the Muslim world. Furthermore, general people of Muslim countries have a soft corner towards social enterprises; consequently, by designing proper strategy social entrepreneurs can create a good demand of their products and thereby make the social enterprises successful which will ensure social equity in the Muslim society.

In this paper the guidelines of developing social enterprises by using crow-funding from Islamic perspective is discussed. The paper suggests that the social enterprises of Muslim world can also use different models (donation, reward, Qardee Hasana, equity) of crowdfunding for the smooth development of social enterprise and thereby their development can be accelerated. The paper also suggests that the governments of Muslim countries should come forward in encouraging (by proving policy supports) the social entrepreneurs in developing sufficient numbers of social enterprises by using different models of crowdfunding (donation, reward, Qardee Hasana, equity). Though the concept of crowdfunding is developed by the west, the concept can be used in islamic societies by simple modification as proposed by this paper. Indeed, Islamic crowdfunding models are different from traditional one from the perspectives of content, philosophy and sprit; because, Islamic crowd-funding must be formed and managed as per the guidelines of the Quran and Sunnah. Thus, this study 
will help those social entrepreneurs who would like to manage their fund from shariah approaved crowd-funding for the betterment of organizational performance as well as for ensuring salvation in the hereafter. Finally, this paper suggests that further study should be conducted to know the real performance of those social enterprises which are using the different models of Islamic crowdfunding with a view to understand the true benefits as well as to identify the problems of social enterprise so that necessary policies can be devised to ensure the smooth development of social enterprise in the Muslim world.

\section{References}

Belleflamme, P., Lambert, T., \& Schwienbacher, A. (2014). Crowdfunding: Tapping the right crowd. Journal of Business Venturing, 29(5), 585-609.

Biztaxlaw. (2013). What is a Disregarded Entity - Disregarded Entity Definition.

Brabham, D. C. (2008). Moving the crowd at iStockphoto: The composition of the crowd and motivations for participation in a crowdsourcing application. First Monday, 13(6).

Bremner, R. H. (1996). Giving: Charity and Philanthropy in History. New Brunswick, NJ: Transaction.

Bygrave W. D. (2003). Who Finances Start-ups in the USA? A Comprehensive Study of Informal Investors, 1999-2003. Retrieved from http://sites.kauffman.org/pdf/UN_financing_report.pdf

Chapra, M. U. (1985). Islam and the Economic Challenge. London: International Institute of Islamic Thought.

Choudhury, M. A. (2002). Microenterprise development using Islamic financing and organizational instruments: modality and practicum. Int J Soc Econ, 29(1/2), 119-134.

Collins, L., \& Pierrakis, Y. (2012). The Venture Crowd Crowdfunding equity investment into business.

Crowsourcing.org. (2014). Retrieved from http://www.crowdsourcing.org

De Buysere, K., Gajda, O., Kleverlaan, R., \& Marom, D (2012). A Framework for European Crowdfunding (1st ed.).

Gerber, E. M., Hui, J. S., \& Kuo, P. Y. (2012). Crowdfunding: Why people are motivated to post and fund projects on crowdfunding platforms. In Proceedings of the International Workshop on Design, Influence, and Social Technologies: Techniques, Impacts and Ethics.

Hoque, N., Khan, M. A., \& Mohammad, K. D. (2015). Poverty alleviation by Zakah in a transitional economy: a small business entrepreneurial framework. Journal of Global Entrepreneurship Research, 5(1), 1-20.

Howe J. (2006). The rise of crowdsourcing. Retrieved from http://www.wired.com/wired/archive/14.06/crowds.html

Howe, J. (2008). Crowdsourcing: How the power of the crowd is driving the future of business. New York: Random House.

Ingenhoff, D., \& Koelling, A. M. (2009). The Potential of Web Sites as a Relationship Building Tool for Charitable Fundraising NPOs. Public Relations Review, 35(1), 66-73.

Kerlin, J. (2009). Social Enterprise: A Global Comparison. University Press of New England.

Kleemann, F., Vob, G., \& Rieder, K. (2008). Un (der) paid Innovators: The Commercial Utilization of Consumer Work through Crowdsourcing. Science Technology and Innovation Studies, 4, 5-26.

Laghari, J. (2013). The Express Tribune. Retrieved from http://tribune.com.pk/story/563435/gdp-40pc-of-muslimstates-population-fall-below-poverty-line

Lambert, T., \& Schwienbacher, A. (2010). An empirical analysis of crowdfunding. Social Science Research Network.

Lane, F. C. (1944). Family Partnerships and Joint Ventures in the Venetian Republic. The Journal of Economic History, 4(2), 178-196.

Leadbeater, C. (2007). Social enterprise and social innovation: Strategies for the next ten years. A social enterprise think piece for the Cabinet Office of the Third Sector. Retrieved from $\mathrm{http}: / / \mathrm{www}$. innovationsociale.lu/sites/default/files/2007_Social\%20enterprise_\%26_SI_Strategyfor10years_ 2007.pdf.

Lehner, O. M. (2013). Crowdfunding Social Ventures: A Model and Research Agenda. Routledge Venture Capital Journal, 15(3). 
Lévy, P. (1997). Collective Intelligence: Mankind's Emerging World in Cyberspace. Helix Books.

Mollah, R., I. (2012). Mainstreaming the Third Sector Economics by Adopting the Principles of Islamic Entrepreneurship: For Development with Equity and Social Justice. IIUC Studies, 9, 39-58.

Morduch, J. (1999). The Microfinance Promise. Journal of Economic Literature, 37(4), 1569-1614.

Nyssens, M. (2006). Social enterprise. At the crossroads of market, public policies.

Ordanini, A., Miceli, L., Pizzetti, M., \& Parasuraman, A. (2011). Crowd-funding: Transforming customers into investors through innovative service platforms. Journal of Service Management, 22(4), 443-470.

Ridley-Duff, R. J., \& Bull, M. (2011). Understanding Social Enterprise: Theory and Practice. London: Sage Publications.

Ridley-Duff, R. J., \& Southcombe, C. (2011). The Social Enterprise Mark: a critical review of its conceptual dimensions. 34th International Small Business and Entrepreneurship Conference, Sheffield. Winner of 'Best Research and Knowledge Transfer Paper in Conference.

Rubinton, B. J. (2011). Crowdfunding: disintermediated investment banking. FINE 547 Advanced Finance Seminar. Retrieved on 8th June 2013 from http://mpra.ub.uni-muenchen.de/31649/

Sadeq, A. H. M. (1996). Ethico-economic institution of Zakah: an instrument of self-reliance and sustainable Grassroot development. Humanomics, 12(2), 47-69.

Schwienbacher, A., \& Larralde, B. (2010). Crowdfunding of small entrepreneurial ventures. Handbook Of Entrepreneurial Finance. Oxford University Press.

Surowiecki, J. (2004). The Wisdom of Crowds: Why the Many are Smarter than the Few and How Collective. Wisdom Shapes Business, Economies, Societies, and Nations.

The Nation. (2011). Retrieved from http://www.nation.com.pk/pakistan-news-newspaper-daily-english-online/business/25-Apr-2011/44pc-of-po vertyhit-live-in-Muslim-countries

World Bank. (2010). Poverty profile in Muslim world. Accessed May 11, 2013, from http://www.worldbank.org

World Bank. (2013). Crowdfunding's potential for the developing world. Retrieved on July 112015 from http://www.infodev.org/infodev-files/wb_crowdfundingreport-v12.pdf

\section{Copyrights}

Copyright for this article is retained by the author(s), with first publication rights granted to the journal.

This is an open-access article distributed under the terms and conditions of the Creative Commons Attribution license (http://creativecommons.org/licenses/by/4.0/). 